\title{
Genetic diversity and sensory preference in pomegranate fruits
}

\author{
Lina MAYUONI-KIRSHeNBAUM ${ }^{1,3}$, Irit BAR-YA'AKov ${ }^{2}$, Kamel HATIB $^{2}$, Doron Holland ${ }^{2}$, Ron PORAT ${ }^{{ }^{*}}$
}

${ }^{1}$ Dep. Postharvest Sci. Fresh Prod., ARO, Volcani Cent., P.O. Box 6, Bet Dagan 50250, Israel,

rporat@volcani.agri.gov.il

2 Dep. Fruit Tree Sci., ARO, Newe Ya'ar Res. Cent., P.O. Box 1021,

Ramat Yishay 30095

Israel

${ }^{3}$ Currently Ph.D. student at Fac. Agric. Food Environ. Qual. Sci. Hebr. Univ. Jerus., Rehovot 76100,

Israel

* Correspondence and reprints

Received 28 November 2012 Accepted 22 February 2013

Fruits, 2013, vol. 68, p. 517-524 (C) 2013 Cirad/EDP Sciences All rights reserved

DOI: 10.1051/fruits/2013090

www.fruits-journal.org

RESUMEN ESPAÑOL, p. 524

\section{Genetic diversity and sensory preference in pomegranate fruits.}

Abstract-Introduction. The aims of our study were to evaluate the genetic diversity in flavor attributes of and preferences for fresh pomegranate arils. Materials and methods. Experiments were conducted with fresh arils extracted from 18 distinct pomegranate varieties within the Israel Pomegranate Breeding Collection of the ARO. Consumer flavor acceptance tests were conducted at a commercial supermarket branch, and descriptive flavor analysis tests were conducted by a trained sensory panel. Results and discussion. Consumer flavor acceptance tests revealed wide diversity in the flavor preferences for various pomegranate varieties. Further descriptive flavor analysis tests revealed that arils from highly preferred varieties were characterized by high sweetness, moderate to low acidity levels, rich red wine and pomegranate fruity odors, low bitterness and astringency, and soft seeds. In contrast, arils from the least preferred varieties were either too sour or bitter, had low red wine and pomegranate fruity odors, or had very hard seeds. Furthermore, all "sour" varieties tested (acid content $\geq 1.8 \%$ ) received low sensory preference scores, whereas "sweet-sour" and "sweet" varieties (acid contents $0.7-1.8 \%$ and $\leq 0.7 \%$, respectively) achieved variable flavor preference scores. Overall, it is suggested that pomegranate flavor preference derives mainly from high sweetness, low to moderate acidity, rich red wine and pomegranate fruity odors, and soft seeds.

Israel / Punica granatum / fruits / organoleptic analysis / variety choice / flavor / sweetness / consumer surveys

\section{Diversité génétique et préférences gustatives de grenades.}

Résumé - Introduction. Les objectifs de notre étude ont été d'évaluer la diversité génétique des composantes du goût et des préférences des arilles de grenades fraîches. Matériel et méthodes. Des expérimentations ont été menées avec des arilles frais extraits des fruits de 18 variétés distinctes de grenadiers issus de la collection génétique israélienne de grenadiers de l'ARO. Des tests d'acceptation de la saveur lors de la consommation des fruits ont été effectués en supermarché, et des tests descriptifs de l'analyse de la perception gustative ont été menés par un panel sensoriel expérimenté. Résultats et discussion. Les tests d'acceptation de la saveur lors de la consommation des fruits ont révélé une grande diversité dans les préférences gustatives des fruits des différentes variétés de grenadiers étudiées. Les analyses de la perception gustative ont révélé que le goût des arilles des variétés préférées était caractérisé par une grande douceur, un taux d'acidité modéré à faible, des sensations de vin rouge et de grenades fruitées, une faible amertume et une faible astringence et des fruits contenant des graines tendres. En revanche, les arilles des fruits des variétés les moins appréciées étaient trop aigres ou trop amers, avaient une faible odeur de vin rouge et de grenade fruitée, ou contenaient des graines très dures. En outre, toutes les variétés « aigres » testées (teneur en acide $\geq 1,8 \%$ ) ont reçu de faibles scores de préférences sensorielles, tandis que les variétés « aigres-douces » et « douces » (teneurs en acide $0,7-1,8 \%$ et $\geq 0,7 \%$, respectivement) atteignaient des scores de préférence variables. Dans l'ensemble, il apparaît que la préférence gustative des grenades serait principalement liée à une grande douceur de l'arille, une acidité faible à modérée, des odeurs de vin rouge et de grenades fruitées et la présence de graines tendres.

Israël / Punica granatum / fruits / analyse organoleptique / choix des variétés / flaveur / douceur / enquête auprès des consommateurs 


\section{Introduction}

Pomegranates (Punica granatum L.) originated in Central Asia (Iran, Turkmenistan and northern India) from where, thousands of years ago, they were probably dispersed throughout the Mediterranean Basin to the rest of the world, including Asia, North Africa, Europe and, later, to North and South America [1]. Overall, there are more than 500 known pomegranate varieties worldwide, of which several dozens are commonly cultivated $[2,3]$. Obviously, genetically different varieties exhibit differing growth characteristics and fruit quality attributes, including size, color, shape, seed hardness, taste and flavor [1, 2]. Recent scientific studies demonstrated that pomegranates provide a rich and unique source of bioactive phytochemicals, and that consumption of pomegranate fruit or juice confers proven medicinal benefits in prevention of serious chronic diseases, such as cardiovascular diseases, diabetes and cancer [4-6] These findings, together with increasing production and sales by major pomegranate-juice manufacturers such as the Californian 'POM Wonderful' and the European 'Pomegreat', have led to dramatic increases in world trading and consumption of pomegranate fruit and juice [7]. Nevertheless, despite the increasing commercial importance of pomegranates, relatively little is known regarding the genetic diversity related to pomegranate flavor traits, or about consumer preferences regarding pomegranate flavor.

In previous studies, pomegranate varieties were generally categorized into three major groups according to their average acidity levels: "sweet", "sweet-sour" and "sour" varieties, which contain mean acidity levels of $0.32 \%, 0.79 \%$ and $2.72 \%$, respectively [8]. However, despite detailed chemical analyses of sugar and acid contents, consumer flavor preferences among the proposed pomegranate classes were not evaluated [8, 9]. Recent sensory evaluation studies suggested that the flavor of pomegranate juices could be characterized by sweet, sour, musty/earthy, fruity aromatic notes and astringent mouth-feel [10]. Furthermore, recent gas chromatography-mass spectrometry (GC-MS) analysis of aroma volatiles of various Spanish and Californian pomegranate varieties revealed that fresh pomegranate juice contained between 18 and 23 aroma volatiles, comprising mainly aldehydes, alcohols and terpenes [11-14]. By characterizing the juice of 'Wonderful' pomegranate fruit, we recently identified 12 aroma-active compounds, which provide a mixture of 'green', 'woody', 'earthy', 'fruity', 'floral', 'sweet' and 'musty' notes [15].

In the present study, consumer flavor acceptance tests and descriptive sensory analysis tests were conducted in order to characterize the flavor of fresh pomegranate arils from 18 distinct varieties. Overall, large genetic diversity in pomegranate flavor preferences was observed, and accordingly, preferred flavor attributes were defined.

\section{Material and methods}

\subsection{Plant material}

Flavor preferences for 18 distinct pomegranate varieties from the Israel Pomegranate Breeding Collection at the Newe Ya'ar Research Center of Israel's Agricultural Research Organization (ARO) were defined. All tested pomegranate varieties are registered in the Israeli Gene Bank for Agricultural Crops (IGB) $)^{1}$ (figure 1). The various pomegranate varieties were harvested from September until November throughout the 2011 and 2012 growth seasons. Each variety was harvested at full maturity, as determined by a combination of maturity indices, including fruit size, color, shape and taste (i.e., loss of astringency), as well as the breeding team's personal experience.

\subsection{Chemical analysis}

For chemical analysis, fruits were cut with a knife, the arils were separated manually and placed within four layers of Miracloth, and the juice was extracted by squeezing and collected into beakers.

1 Web site: http://igb.agri.gov.il. 


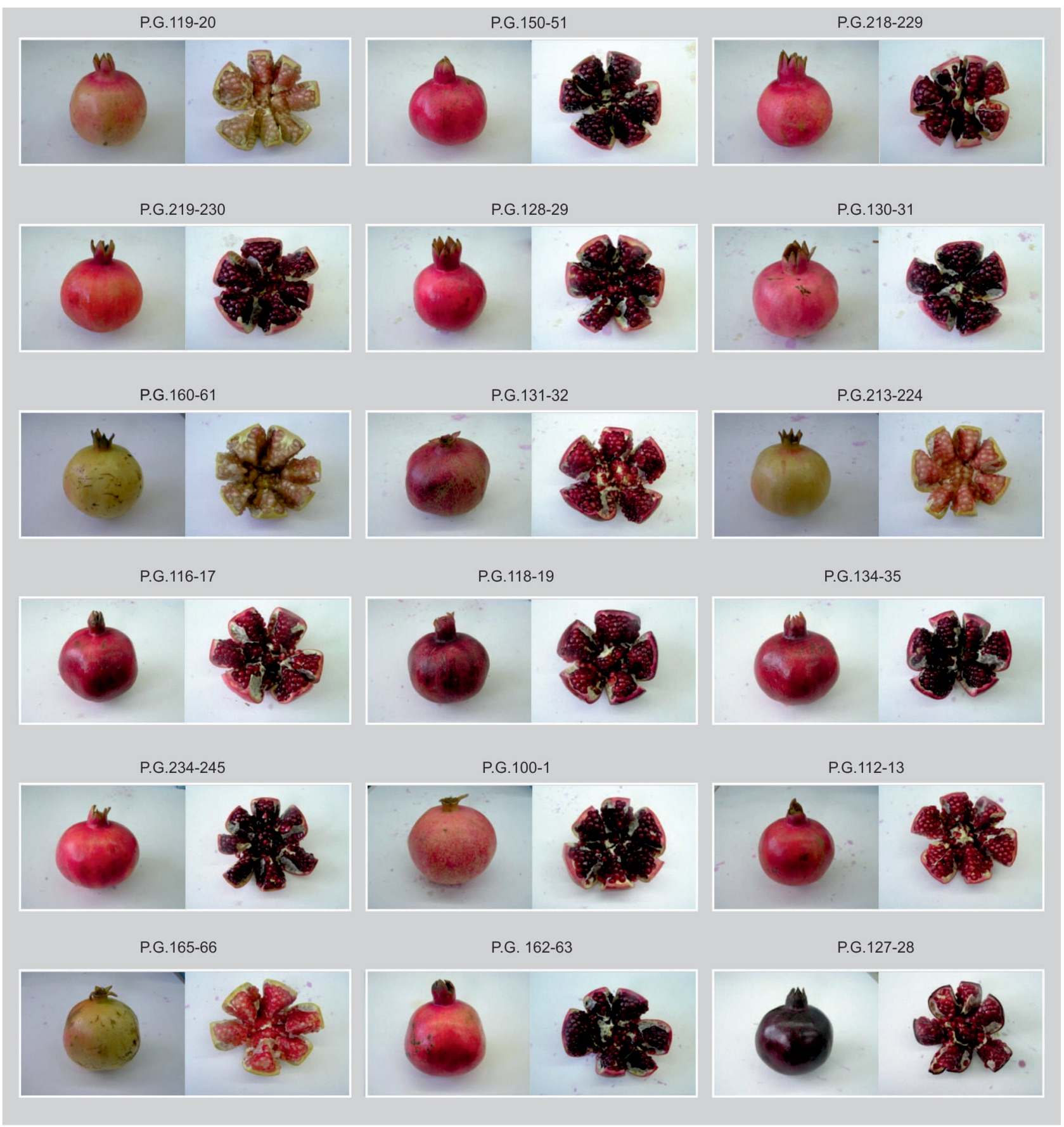

\section{Figure 1.}

Fruits of 18 distinct pomegranate varieties from the pomegranate collection of Israel's Agricultural Research Organization (ARO), evaluated to study their genetic diversity and sensory preference.

Total soluble solids (TSS) content in the acidity percentages were measured by juice was determined with a PAL-1 digital titration to $\mathrm{pH} 8.3$ with $0.1 \mathrm{M} \mathrm{NaOH}$ in a CHrefractometer (Atago, Tokyo, Japan), and 9101 automatic titrator (Metrohm, Herisau, 
Switzerland). Each measurement included five replications, each using juice collected from two fruits, i.e., a total of 10 fruits per measurement.

\subsection{Sensory evaluations}

The sensory quality of separated arils was evaluated by acceptance and descriptive tests [16]. In all cases, separated arils were extracted from at least five different fruits and placed in plastic cups identified by randomly assigned three-digit codes. Consumer sensory acceptance tests were evaluated according to a 9-point hedonic scale ranging from "very strong dislike" to "very strong like". The consumer flavor acceptance tests were conducted at Shufersal Deal Supermarket, Rishon Lezion, Israel, and included between 80-90 consumer evaluations per variety.

Descriptive flavor analysis tests were conducted by a trained sensory panel of 10 members - five males and five females, aged 25 to 62 . Each panelist assessed the various attributes of the samples according to an unstructured 100-mm scale for each attribute, with the anchor points "very weak" and "very strong", and sensory data were recorded as distances ( $\mathrm{mm}$ ) from the origin The trained sensory panel gathered three times prior to the experiments in order to define the provided sensory attributes, and practiced by performing open discussion panels, in order to normalize perceived flavor attribute intensities among all members. All sensory panel members were technicians or students working in the Department of Postharvest Science at the ARO, the Volcani Center (Israel), already familiar with sensory analysis and evaluation $[17,18]$. The sensory attributes chosen by the trained panel were: taste (sweet, sour and bitter), odor (red wine, and pomegranate fruity notes), and mouth-feel sensations (astringency, juiciness and seed hardness). The attribute of "red wine" odor corresponds to the "wine-like" definition provided by Koppel and Chambers [10], describing the sharp fruity alcohol-like aroma associated with red wine.

\subsection{Statistical analysis}

One-way analysis of variance (ANOVA) and Tukey's HSD pairwise comparison tests were applied by means of the JMP statistical software program, version 7 (SAS Institute Inc., Cary, NC, USA).

\section{Results}

The flavor preferences for 18 distinct pomegranate varieties selected from the Israeli Pomegranate Breeding Collection at the Newe Ya'ar Research Center were examined. These pomegranate varieties had distinct shapes, and a range of external peel and aril colors including red, pink and white/yellowish (figure 1).

The selected pomegranate varieties exhibited remarkable differences among their juice TSS and acidity levels. Overall, juice TSS levels ranged from $14.2 \%$ to $17.5 \%$, and juice acidity levels from just $0.3 \%$ to $3.2 \%$ (figure 2). These observed differences in total TSS and acidity levels resulted in remarkable differences in juice [TSS/acidity] ratios (fruit ripening ratios) from just 5 through 74 (figure 2). Furthermore, the observed differences in juice [TSS/acidity] ratios were primarily governed by the observed differences in acidity levels rather than by differences in TSS levels (figure 2).

By conducting consumer acceptance tests, remarkable differences in the overall flavor preference ratings for the various pomegranate varieties were found, ranging from very high scores (7.9; variety P.G.100-1) through low scores (4.1; variety P.G.162-63), thus demonstrating the wide genetic diversity associated with pomegranate fruit flavor acceptability (figure 3). In the past, pomegranate varieties were divided according to their acidity levels into "sweet", "sweetsour" and "sour" varieties [8]. Therefore, in order to determine the importance of the sweetness and sourness traits for pomegranate flavor preference, we classified the presently tested varieties as "sweet" (acidity levels below 0.7\%), "sweet-sour" (acidity levels of $0.7-1.8 \%$ ) and "sour" varieties (acidity levels above 1.8\%). Sorting according to this classification revealed that all 
three tested "sour" varieties (P.G.162-63, P.G.165-66 and P.G.112-13) received the lowest flavor preference scores, whereas the "sweet" and "sweet-sour" varieties received divergent flavor preference scores (figure 3). These results suggest that "sour" varieties are not preferred, and that other flavor attributes, in addition to just sweetness and acidity, are also involved in determining pomegranate flavor acceptance. Another factor that putatively might affect flavor preference is aril color, but we did not detect any meaningful correlations among the various aril colors, such as "dark red", "red", "pink" or "white", and observed flavor preferences (figure 4). Thus, aril color does not significantly influence its perceived flavor.

To better elucidate which flavor attributes are important in defining pomegranate flavor preferences, we examined the flavor profiles of the tested varieties with the aid of a trained sensory panel. The five most preferred varieties (consumer flavor preference scores above 7.0) shared more or less similar flavor profiles, including relatively high sweetness, moderate to low sourness scores, high red wine and pomegranate fruity flavor notes, low bitterness and astringency scores, and medium to soft seeds (figure 5A). According to these findings, an average preferred pomegranate flavor profile was composed (figure 5B).

In contrast to the preferred pomegranate flavor profile, the six least preferred varieties, which achieved flavor preference scores below 6.0, could be distinguished from the preferred flavor profiles according to various parameters (figure 6 ). For example, the varieties P.G.162-63, P.G.165-66 and P.G.112-13 were very sour; P.G.219-230 was very bitter; P.G.119-20, P.G.213-224, P.G.165-66 and P.G.162-63 had low red wine and pomegranate fruity odors; and P.G.119-20 and P.G.112-13 had extremely hard seeds (figure O).

\section{Discussion}

Despite the increasing importance of pomegranates in global trading and juice consumption, and their important nutritional contributions to the human diet, very little

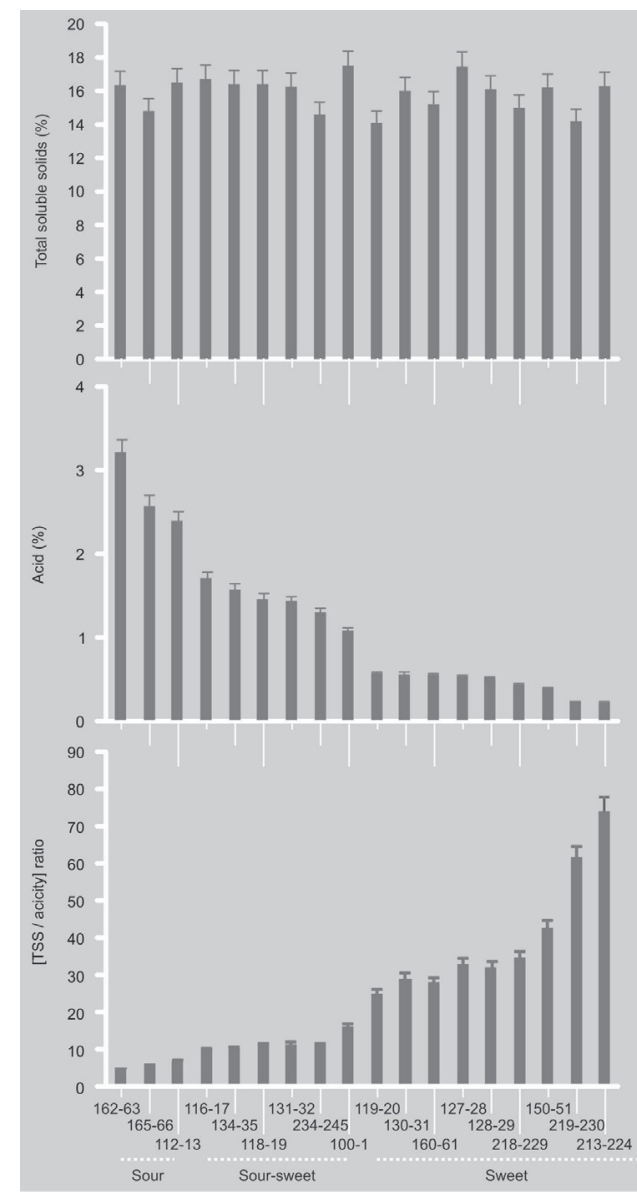

Figure 2.

Total soluble solids, acid contents and [TSS/acid] ratios in fruit juices of 18 distinct pomegranate varieties. Data are means \pm standard errors of five replications, each using juice collected from two fruits (i.e., total of 10 fruits per measurement).

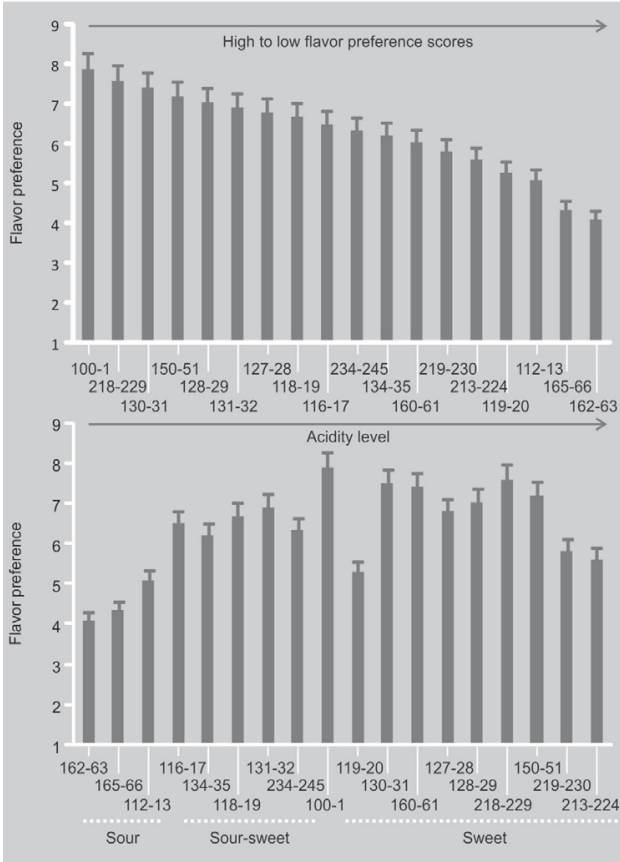

Figure 3.

Consumer flavor preference scores of pomegranate arils extracted from 18 distinct pomegranate varieties. Data are means \pm standard error of 70 testers. In the upper panel, the pomegranate varieties are presented in order from high to low flavor preference scores; in the lower panel they are classified according to their acidity levels ("sweet" varieties, acid levels $<0.7 \%$, "sweet-sour" varieties, acid levels $0.7-1.8 \%$, and "sour" varieties, acid levels $>1.8 \%$ ). 
Figure 4.

Consumer flavor preference scores of pomegranate arils extracted from 18 distinct pomegranate varieties. Data are means \pm standard error of 70 testers. The pomegranate varieties were classified according to their aril colors (see figure 1).
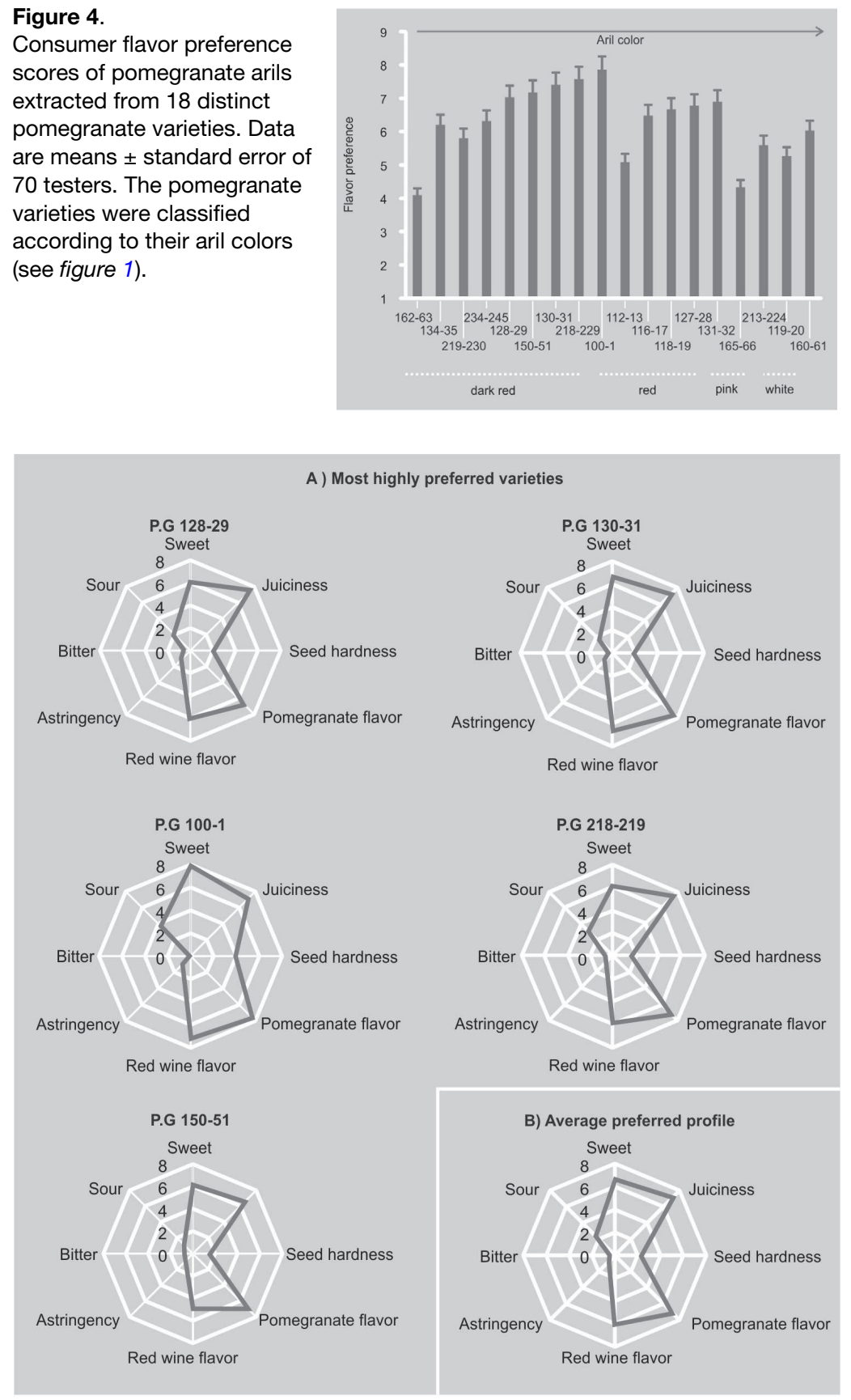

\section{Figure 5.}

Evaluation of sensory quality of pomegranate arils. A) flavor is known regarding the genetic diversity of profiles of arils from the five pomegranate flavor traits, or about conmost highly preferred varieties. sumer sensory preferences for pomegranate B) average flavor profile of highly preferred pomegranate fruits. Fruit flavors were evaluated by a trained taste panel. Data are means of 10 replications. fruits. In our present study, wide genetic diversity associated with flavor traits and sensory preferences among 18 distinct pomegranate varieties were explored.
According to sensory analysis evaluations with the aid of a trained panel, it was suggested that the main flavor attributes required to characterize the flavor of freshly extracted pomegranate arils include taste (sweet, sour, bitter), odor (red wine and pomegranate fruity notes) and mouth-feel sensations (astringency, juiciness and seed hardness). Pomegranate varieties that achieved overall high consumer flavor preference scores were characterized by high sweetness, moderate to low acidity levels, rich red wine and pomegranate fruity odors, low bitterness and astringency, and, preferably, soft seeds. In contrast, varieties with low flavor preference scores were either too sour or bitter, had low red wine and pomegranate fruity odors, or had very hard seeds. This information regarding the sensory preference ratings of pomegranates is obviously very important to pomegranate breeders, growers, exporters, buyers and juice manufacturers, as it might assist in future selection of new desired pomegranate varieties with high consumer sensory preference scores. Nevertheless, it is worth noting that the desired pomegranate flavor preference may differ among distinct cultures and countries. For example, in the Far East and North Africa, consumers often prefer sweet fruit, whereas in Russia and other Northern countries, consumers may prefer more sour fruit [9].

In the past, pomegranate varieties were classified into three major groups according to their acidity levels, i.e., "sweet", "sweetsour" and "sour" varieties [8]. Nevertheless, despite detailed biochemical analyses of sugar and acid contents in these fruits, it still remained unclear which of these diverse "sweet", "sweet-sour" and "sour" varieties were more preferred. In our present study, it was found that all three tested "sour" varieties achieved low sensory preference scores, whereas "sweet" and "sweet-sour" varieties achieved divergent scores. These findings present two major implications: 1) "sweet" and "sweet-sour" pomegranate varieties are favored and more preferred as compared with "sour" varieties; and 2) other factors besides sweetness and sourness have crucial importance in determining pomegranate flavor preference. Our results suggest that these other factors of sensory 


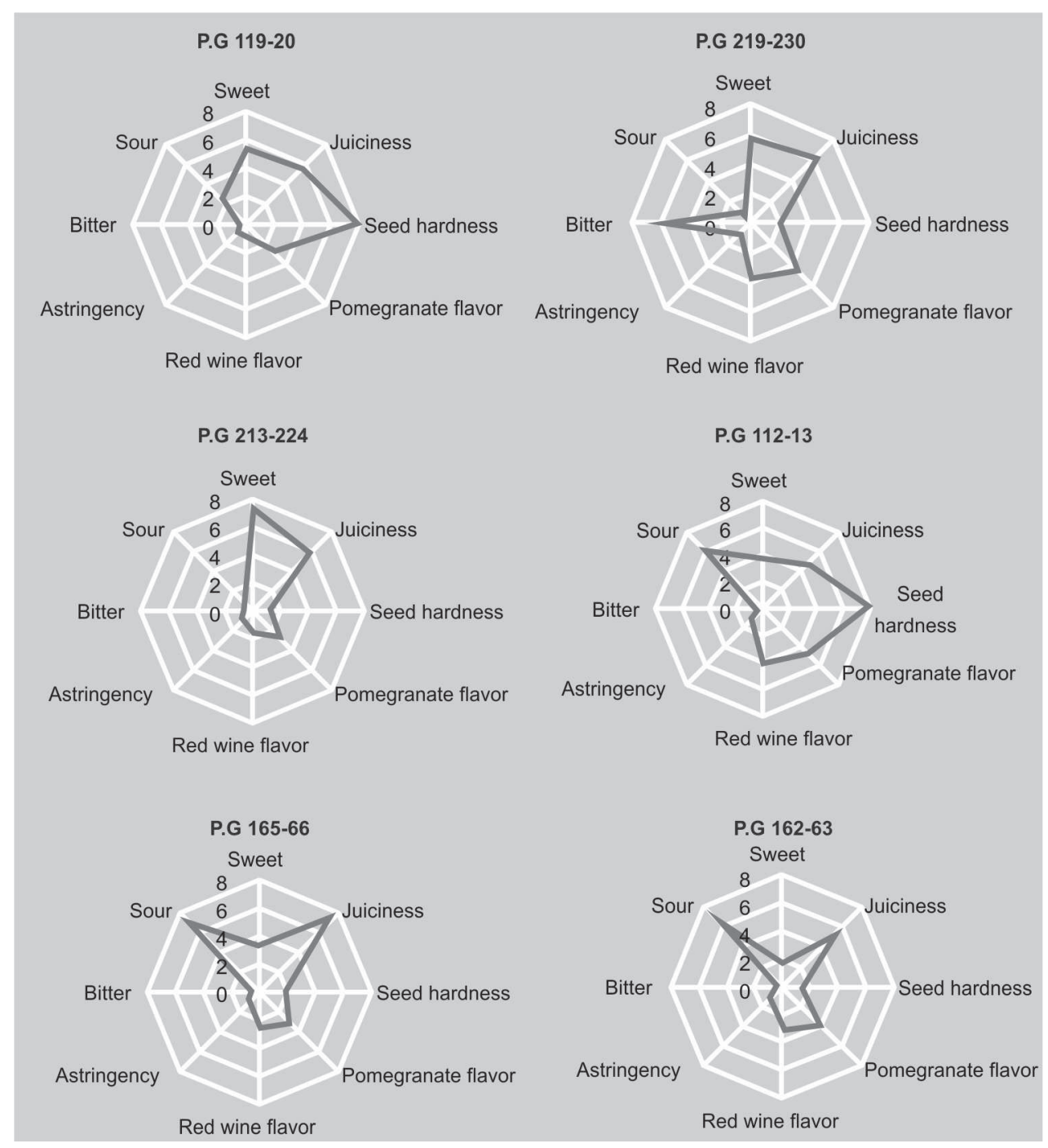

attributes are mainly rich red wine and pomegranate fruity odors, low bitterness and astringency, and soft seeds.

\section{Acknowledgments}

This manuscript is contribution no. 631/12 from the Agricultural Research Organization, the Volcani Center, P.O. Box 6, Bet Dagan 50250, Israel.

\section{References}

[1] Holland D., Hatib K., Bar-Ya'akov I., Pomegranate: botany, horticulture, breeding, Hortic. Rev. 35 (2009) 127-191.
[2] Stover E., Mercure E.W., The pomegranate: a new look at the fruit of paradise, HortScience 42 (2007) 1088-1092.

[3] Still D.W., Pomegranates: A botanical perspective, in: Seeram N.P., Schulman R.N., Heber D. (Eds.), Pomegranates ancient roots to modern medicine, CRC Press, Taylor \& Francis Group, Boca Raton, FL, U.S.A., 2006, pp. 211-222.

[4] Viuda-Martos M., Fernández-López J., Pérez-Álvarez J.A., Pomegranate and its many functional components as related to human health: a review, Compr. Rev. Food Sci. Food Saf. 9 (2010) 635-654.

[5] Johanningsmeier S.D., Harris G.K., Pomecal source, Annu. Rev. Food Sci. Technol. 2 (2011) 181-201. granate as a functional food and nutraceuti-
Figure 6.

Evaluation of sensory quality of pomegranate arils extracted from the six least preferred varieties. Fruit flavors were evaluated by a trained taste panel. Data are means of 10 replications. 
[6] Facial A., Ocalhau C.A., The bioactivity of pomegranate: impact on health and disease, Crit. Rev. Food Sci. Nutr. 51 (2011) 626-634.

[7] Rymon D., Mapping features of the global pomegranate market, Acta Hortic. 890 (2011) 599-602.

[8] Melgarejo P., Domingo M.S., Artes F. Organic acids and sugar composition of harvested pomegranate fruits, Eur. Food Res. Technol. 211 (2000) 185-190.

[9] Dafny-Yalin M., Glazer I., Bar-Ilan I., Kerem Z., Holland D., Amir R., Color, sugars and organic acids composition in aril juices and peel homogenates prepared from different pomegranate accessions, J. Agric. Food Chem. 58 (2010) 4342-4352.

[10] Koppel K., Chambers E., Development and application of a lexicon to describe the flavor of pomegranate juice, J. Sens. Stud. 25 (2010) 819-837.

[11] Vázquez-Araújo L., Koppel K., Chambers E., Adhikaria K., Carbonell-Barrachina A.A., Instrumental and sensory aroma profile of pomegranate juices from the USA: differences between fresh and commercial juice, Flav. Fragr. J. 26 (2011) 129-138.

[12] Vázquez-Araújo L., Chambers E., Adhikaria K., Carbonell-Barrachina A.A., Physico-chemical and sensory properties of pomegranate juices with pomegranate albedo and carpellar membranes homogenate, LWT Food Sci. Technol. 44 (2011) 2119-2125.

[13] Melgarejo P., Ín-Sánchez A.C., VázquezAraújo L., Hernández F., José Martínez J., Legua P., Carbonell-Barrachina A.A., Volatile composition of pomegranates from 9 Spanish cultivars using headspace solid phase microextraction, J. Food Sci. 76 (2011) 114-120.

[14] Calín-Sánchez A., Martínez J.J., VázquezAraújo L., Burló F., Melgarejo P., CarbonellBarrachina A.A., Volatile composition and sensory quality of Spanish pomegranates (Punica granatum L.), J. Sci. Food Agric. 91 (2011) 586-992.

[15] Mayuoni L., Tietel Z., Porat R., Ulrich D., Identification of aroma-active compounds in 'Wonderful' pomegranate fruit using solventassisted flavour evaporation and headspace solid-phase micro-extraction methods, Eur. Food Res. Technol. 235 (2012) 277-283.

[16] Lawless H.T., Heymann H., Sensory evaluation offood, Kluwer Acad. Publ., N.Y., U.S.A., 1999.

[17] Mayuoni L., Tietel Z., Patil B.S., Porat R., Does ethylene degreening affect internal quality and flavor of citrus fruit? Postharvest Biol. Technol. 62 (2011) 50-58.

[18] Tietel Z., Lewinsohn E., Fallik E., Porat R., Elucidating the roles of ethanol fermentation metabolism in causing off-flavors in mandarins, J. Agric. Food Chem. 59 (2011) 1177911785.

\section{Diversidad genética y preferencias gustativas de las granadas.}

Resumen - Introducción. Los objetivos de nuestro estudio fueron evaluar la diversidad genética de los componentes del gusto y las preferencias de arilos de granadas frescas. Material y métodos. Se llevaron a cabo experimentos con arilos frescos de 18 variedades distintas de granados extraídos de la colección genética de granados de la organización de investigación agrícola israelí (ARO). Se realizaron pruebas de aceptación del sabor en supermercados, así como experimentos descriptivos del análisis de la percepción gustativa por parte de un grupo de expertos sensoriales. Resultados y discusión. Las pruebas de aceptación del sabor tras el consumo de frutas revelaron una gran variedad en las preferencias gustativas según los distintos tipos de granados estudiados. Los análisis de la percepción gustativa revelaron que el sabor preferido de los arilos de las variedades estudiadas se caracterizaba por un gran dulzor, un índice de acidez de moderado a débil sensaciones de vino tinto y de granadas afrutadas, una ligera amargura, una ligera astringencia, y frutas de granos tiernos. Por el contrario, los arilos de las frutas de las variedades menos apreciadas eran demasiado agrios o demasiado amargos, tenían poco olor a vino tinto o a granada afrutada, o contenían granos muy duros. Asimismo, todas las variedades "agrias" del experimento (contenido en ácido $\geq 1,8 \%$ ) recibieron bajas puntuaciones de preferencias sensoriales, mientras que las variedades "agridulces" y "dulces " (contenido en ácido 0,7-1,8\% y $\leq 0,7 \%$, respectivamente) alcanzaron puntuaciones de preferencia variables. En conjunto, parece que la preferencia gustativa de las granadas está ligada, sobre todo, a un gran dulzor del arilo, una acidez de débil a moderada, olor a vino tinto y a granadas afrutadas y la presencia de granos tiernos.

Israel / Punica granatum / frutas / análisis organoléptico / elección de variedades / sabor / dulzura / encuestas al consumidor 